\title{
Synthesis and Characterization of Calcium Oxide Nanoparticles from Duck Eggshells using Ball Milling Methods
}

\author{
Ade Yeti Nuryantini $^{1^{*}}$, Citra Deliana Dewi Sundari ${ }^{2}$, Halimahtussa'diah $^{3}$, Bebeh Wahid \\ Nuryadin $^{3}$
}

${ }^{1}$ Department of Physics Education, Faculty of Tarbiya and Teacher Training, UIN Sunan Gunung Djati

Bandung, Jl. Cimincrang, Cimenerang, Panyileukan, Bandung, West Java, 40292, Indonesia.

${ }^{2}$ Department of Chemistry Education, Faculty of Tarbiya and Teacher Training

UIN Sunan Gunung Djati Bandung, J1. Cimincrang, Cimenerang, Panyileukan, Bandung, West Java, 40292, Indonesia.

${ }^{3}$ Department of Physics, Faculty of Science and Technology, UIN Sunan Gunung Djati Bandung

Jl. A.H. Nasution 105, Bandung - Indonesia 40614

*Corresponding author: ade.yeti@uinsgd.ac.id

Received: August 2018; Revision: November 2018; Accepted: December 2019; Available online: December 2019

\begin{abstract}
Calcium oxide $(\mathrm{CaO})$ nanoparticles have been successfully synthesized from duck eggshells using ball milling method followed by simple calcination at $700{ }^{\circ} \mathrm{C}$ for 7 hours. The observation on the morphology, size and shape of the particles of the eggshells powder was conducted through scanning electron microscope (SEM). The milling time was varied, i.e. $2,6,10$, and 20 hours to observe the difference in the size of the produced particle. SEM images show that the smallest average particle diameter is $520 \mathrm{~nm}$, achieved by 20 hours of milling. When the particles were calcined, the average diameter was further reduced to $394 \mathrm{~nm}$. The X-ray diffraction (XRD) analysis shows that the resulting particles contain calcium oxide, calcium hydroxide, and calcium carbonate.
\end{abstract}

Keywords: Ball milling method, calcium oxide nanoparticle, duck eggshell, simple calcination.

DOI:10.15408/jkv.v5i2.879.

\section{INTRODUCTION}

Duck eggshells are often considered as waste without any significant use. This view can be proven wrong, however, since it was already found that eggshells contain up to $96 \%$ calcium carbonate and many other inorganic materials such as magnesium, phosphorus, and a variety of trace elements (Hincke et al., 2004). The high content of calcium carbonate from the eggshells can then be extracted and used for drugs, pharmaceutical, industries, drug delivery system, food supplement for livestock, toothpaste, paper, bioplastic, component in inkjet for paper layer, and as replacement of chalk or supplement calcium in agriculture. Additionally, it can be used to assist the process of hydrogen purification, insect eradicator, fertilizer, catalyst production and production of calcium oxide (Ashok et al., 2015; Kamba et al., 2013).
By processing the eggshell powder further, pure calcium oxide $(\mathrm{CaO})$ (Shakhashiri, 2003) and hydroxyapatite (Khandelwal and Prakash, 2016; Rivera et al., 1999) can be obtained. There are numerous potential application of calcium oxide $(\mathrm{CaO})$ and hydroxyapatite such as catalyst (Shi et al., 2017), absorbent (Chraibi et al., 2016), biofilter (Yew et al., 2014), and cement production (Ansari et al., 2016).

$\mathrm{CaO}$ is a white solid crystal material, which could be synthesized from eggshells by calcination at 500-600 ${ }^{\circ} \mathrm{C}$ (Shakhashiri, 2003). The reaction of the duck eggshell powder calcination is the conversion of $\mathrm{CaCO}_{3}$ to $\mathrm{CaO}$ and $\mathrm{CO}_{2}$, as follows:

$$
\mathrm{CaCO}_{3}(\mathrm{~s}) \rightarrow \mathrm{CaO}(\mathrm{s})+\mathrm{CO}_{2}(\mathrm{~g})
$$

The eggshell powder can be produced by a mechanical process such as ball milling 
methods. Ball milling is a low cost and environmentally friendly method which can be used for massivescale production to produce nanostructured eggshell powder (Gorrasi and Sorrentino, 2015).

This paper reports the synthesis and characterization of calcium oxide nanoparticles synthesized from duck eggshells through ball milling and simple calcination method. The duck eggshells were specifically chosen since it has a higher amount of calcium carbonate compared to chicken eggshells (Dewi et al., 2014). The milling time was varied from 2 to 20 hours to observe the difference in the size of the particle produced. The morphology of the powder was examined using scanning electron microscope (SEM) while the crystallinity was investigated using X-Ray Diffraction (XRD)

\section{MATERIALS AND METHODS}

The duck eggshells were collected as waste from traditional food sellers. The eggshells were separated from shell membranes and then cleaned by using water, while the dirty parts were brushed off. Furthermore, 385 grams of duck eggshells were milled using the ball milling reactor at $100 \mathrm{rpm}$. The number of milling balls used was eight balls, with average diameter of $18 \mathrm{~mm}$. The schematic diagram of the ball milling reactor used is shown in Figure 1.

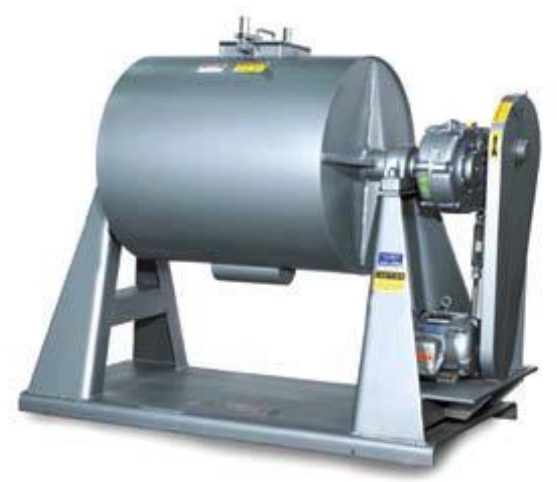

Figure 1. The schematic diagram of the ball milling reactor for the fabrication of duck eggshell powders (Abdullah, 2008).

In order to analyze the effect of milling time, some sample of milled powder was taken every 2 hours as shown in Table 1 . One gram of duck eggshell powder from sample A, C, and D (each was milled for 2, 10, and 20 hours, respectively) was calcined at 700 ${ }^{\circ} \mathrm{C}$ for 7 hours to obtain calcium oxide nanoparticles. The morphology of eggshell powder before and after calcination was analyzed using a scanning electron microscope (SEM). The average diameter of eggshell powder before and after calcination was determined from SEM image of the eggshell powder. The crystal structure of calcium oxide powder was characterized using X-Ray diffraction (XRD).

Table 1. Sample with Variations of Length of Milling.

\begin{tabular}{cccccc}
\hline No. & Sample & $\begin{array}{c}\mathbf{t} \\
(\text { hour })\end{array}$ & $\begin{array}{c}\boldsymbol{v} \\
(\mathbf{R p m})\end{array}$ & $\begin{array}{c}\mathbf{d} \text { ball } \\
(\mathbf{m m})\end{array}$ & $\Sigma$ ball \\
\hline 1 & $\mathrm{~A}$ & 2 & 100 & 18.04 & 18 \\
2 & $\mathrm{~B}$ & 6 & 100 & 18.04 & 18 \\
3 & $\mathrm{C}$ & 10 & 100 & 18.04 & 18 \\
4 & $\mathrm{D}$ & 20 & 100 & 18.04 & 18 \\
\hline
\end{tabular}

\section{RESULTS AND DISCUSSION}

Figure 2 shows the SEM images of duck eggshell powder obtained by ball milling eggshell samples for 2 hours (sample A), 6 hours (sample B), 10 hours (sample C) and 20 hours (sample D). As shown by the SEM images, the shape of the particles in sample A (Figure 2a) were irregular and agglomeration was found. The agglomeration of particles was caused by the strong bonds between the natural proteins with calcium ion $\left(\mathrm{Ca}^{2+}\right)$ (Fatmawati et al., 2012).

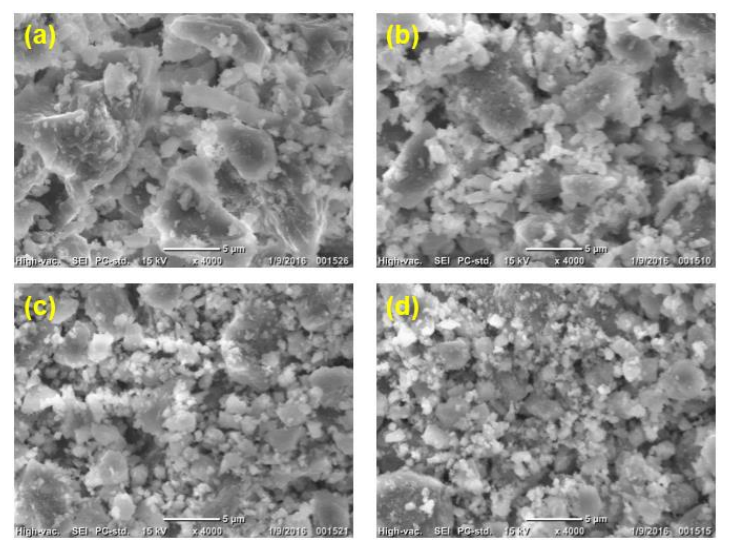

Figure 2. SEM images of duck eggshell powders after being milled for (a) 2 hours (sample A), (b) 6 hours (sample B), (c) 10 hours (sample C), and (d) 20 hours (sample D).

In Figure $2 b$ and $2 c$, the eggshell was milled continuously for a longer milling time, which then caused the particles to collide more frequently. The particles were then split and shrank until the size of the eggshell powder 
became smaller and the proteins that bind the calcium were removed. As the milling time was increased further, the size of the powder became smaller as depicted in SEM images (Figure 2d) proving that, in general, the longer the milling time the smaller the powder will be produced. The collision between the milling balls and the eggshells will remove and separate the proteins which stick on the calcium carbonate.

Figure 3 presents the correlation between milling time and the average diameter of the eggshell powders. The average diameter of eggshell powders was decreased with increasing milling time. The diameter reduction is made by impact as the milling balls drop to the top surface of the eggshell powders. The milling process can thus reduce the size of the powder without changing the characteristics of the compounds (Diana, 2010).

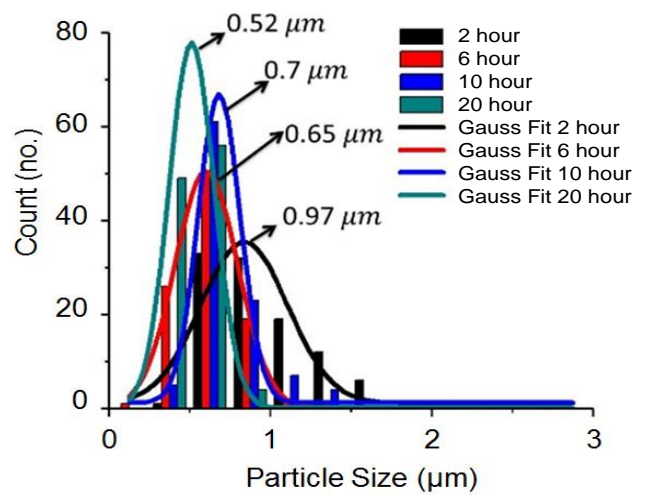

Figure 3.Size distribution of the eggshell powder after milled for 2, 6, 10, and 20 hours (sample A, B, $\mathrm{C}$, and $\mathrm{D}$ respectively).

The eggshell powder samples were calcined. During calcination, the eggshell powders were thermally decomposed to form mainly calcium oxide. The calcination process reduced the total weight of the powder since several elements like carbon and oxygen were released. At $200{ }^{\circ} \mathrm{C}$, water contained in the samples was evaporated due to heat while all organic components, such as protein, were oxidized at $450{ }^{\circ} \mathrm{C}$. The thermal decomposition process, in which the calcium carbonate $\left(\mathrm{CaCO}_{3}\right)$ turned into calcium oxide $(\mathrm{CaO})$, occurred at $540{ }^{\circ} \mathrm{C}$ (Dasgupta et al., 2004). Therefore, the eggshell powders were calcined at $700{ }^{\circ} \mathrm{C}$ for 7 hours in order to successfully produce $\mathrm{CaO}$ powder after the whole process took place. Figure 4 shows the eggshell powder after being calcined at $700{ }^{\circ} \mathrm{C}$ for 7 hours with variation of milling time for sample $\mathrm{A}, \mathrm{C}$, and $\mathrm{D}$.

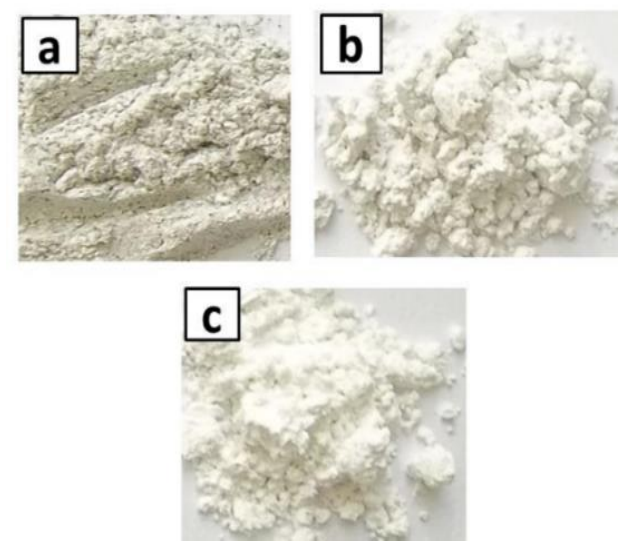

Figure 4. The calcined eggshell powder $\left(700^{\circ} \mathrm{C}, 7\right.$ hours) for sample: (a) A, (b) C, and (c) D.

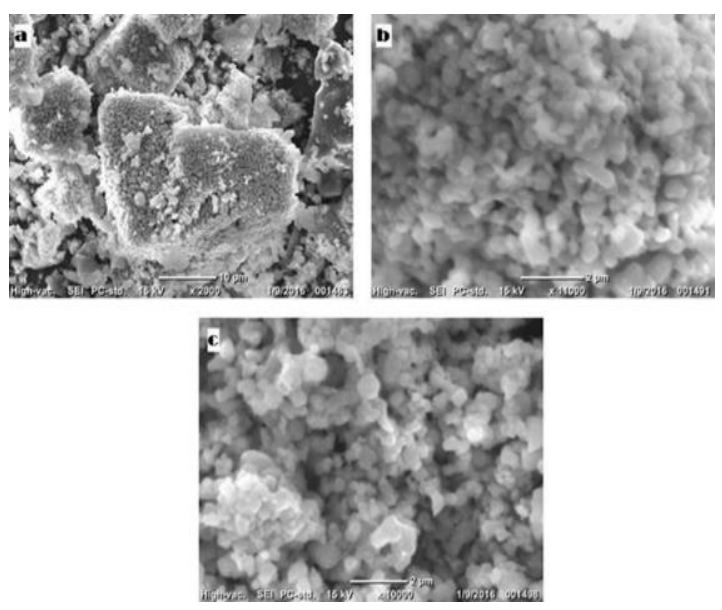

Figure 5. SEM Images of the calcined eggshell powders (700 ${ }^{\circ} \mathrm{C}, 7$ hours) for sample (a) A, (b) C, (c) D.

After calcined, the eggshell powder samples result in different color as shown in in Figure 4. The color of sample D was brighter than sample A and C. Sample A has darker color than sample $\mathrm{C}$ and $\mathrm{D}$. This color difference might be caused by the difference in the degree of completeness of thermal decomposition. High temperature calcination causes bonds between the granules to get smaller, shrinking the pores, and produce white powder (Kurniawan et al., 2014). The brighter/whiter sample color indicates that a complete chemical transformation from $\mathrm{CaCO}_{3}$ to $\mathrm{CaO}$ is is achieved (Tangboriboon et al., 
2012). SEM images and particle size distributions of the calcined eggshell powders can be seen in Figure 5 and Figure 6, respectively.

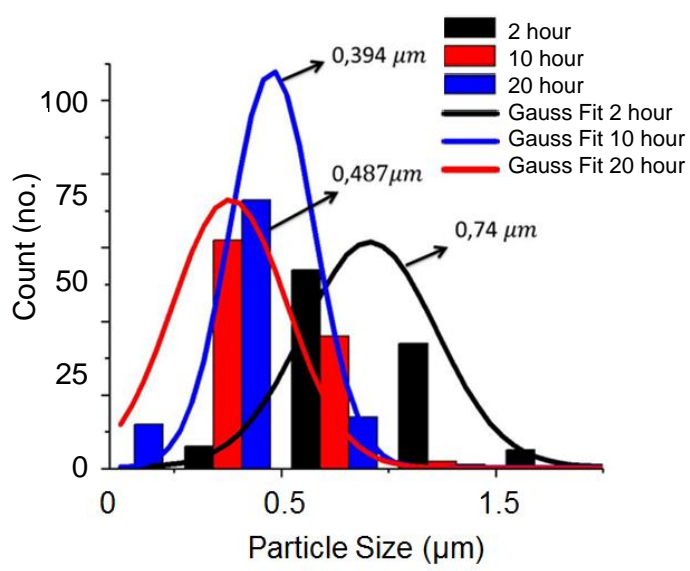

Figure 6. Particle size distribution of the calcined eggshell powders milled for 2, 10, and 20 hours (sample A, C, and D respectively).

From figure 5, it can be seen that the particles size of sample A were larger and more agglomerated than sample $\mathrm{C}$ and $\mathrm{D}$. Calcination process can reduce the diameter of eggshell powder particles. In the calcination process, the particles vibrate to each other, thus the particles split and become smaller. However, the difference in particle size between sample A, C, and D were caused by the difference of milling time, because the calcination temperature and duration for the three samples were the same. From figure 6, it can be seen that sample D has the smallest average particle diameter, i.e. $394 \mathrm{~nm}$.

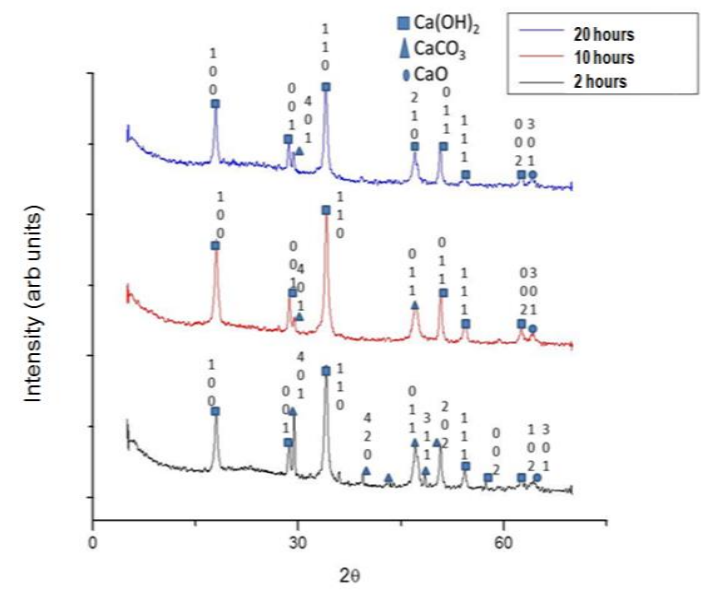

Figure 7. X-Ray Diffractogram of the calcined eggshell powders $\left(700^{\circ}, 7\right.$ hours) milled for 2, 10, and 20 hours (sample A, C, and D respectively).
The calcined sample A, C, and D were then analyzed using X-Ray Diffractometer (XRD). The diffractogram of the three samples can be seen in Figure 7. From Figure 7, it can be seen that all three samples still contain $\mathrm{CaCO}_{3}$, but with different amount. The intensity of $\mathrm{CaCO}_{3}$ diffraction peaks was higher in sample A, which was milled for only 2 hours than sample $C$ and $D$. The short milling time causes bigger particle size, hence smaller surface area, which causes the thermal decomposition reaction goes slower. The reaction did not fully completed. Beside $\mathrm{CaCO}_{3}$ diffraction peaks, $\mathrm{Ca}(\mathrm{OH})_{2}$ and $\mathrm{CaO}$ peaks were observed on the three samples. $\mathrm{Ca}(\mathrm{OH})_{2}$ diffraction peaks were present dominantly due to reactive moisture adsorption (Tangboriboon et al., 2012). This might be caused by sample contact to air moisture. $\mathrm{CaO}$ can be easily hydrated by air moisture forming $\mathrm{Ca}(\mathrm{OH})_{2}(\mathrm{c})$.

\section{CONCLUSION}

Calcium oxide $(\mathrm{CaO})$ was successfully synthesized from duck eggshells via ball milling method with milling time of $2,6,10$, and 20 hours followed by calcination at $700{ }^{\circ} \mathrm{C}$ for 7 hours. SEM images showed that longer milling time leads to a smaller particle size of eggshell powder sample, either before and after calcination. X-ray diffractogram showed that the calcined eggshell powders contain not only $\mathrm{CaO}$, but also $\mathrm{Ca}(\mathrm{OH})_{2}$ and $\mathrm{CaCO}_{3}$. The longer milling time causes smaller particle size, hence bigger surface area, which causes the thermal decomposition reaction goes faster and more complete.

\section{REFERENCES}

Abdullah M. 2008. Pengantar Nanomaterial. Bandung(ID): ITB.

Ansari MM, Kumar MD, Charles JM, Vani G. 2016. Replacement of cement using eggshell powder. SSRG International Journal of Civil Engineering (SSRGIJCE). 3(3): 2-3.

Ashok C, Chakra CS, Dayakar T, Kumar MK, Rao KV. 2015. Calcium oxide nano particles synthesized from chicken egg shells by physical method calcium oxide nano particles synthesized from chicken egg shells by physical method. In International Conference on Emerging Technologies in 
Mechanical Sciences. pp: 72-75). Malla Reddy College of Engineering and Technology II.

Chraibi S, Moussout H, Boukhlifi F, Ahlafi H, Alami M. 2016. Utilization of calcined eggshell waste as an adsorbent for the removal of phenol from aqueous solution. Journal of Encapsulation and Adsorption Sciences. $\quad 6$ : $132-146$. https://doi.org/10.4236/jeas.2016.64010

Dasgupta P, Singh A, Adak S, Purohit KM. 2004. Synthesis and characterization of hydroxyapatite produced from eggshell. Proceeding of International Symposium of Research Students on Materials Science and Engineering. 1-6.

Dewi SU, Dahlan K, Soejoko DS. 2014. The use of hen's and duck's eggshell as calsium source to suynthesis bone mine. Jurnal Pendidikan Fisika Indonesia. 10(95): 8185.

https://doi.org/10.15294/jpfi.v10i1.3054

Diana FN. 2010. Simulasi dengan metode monte carlo untuk proses pembuatan nanomaterial menggunakan ball mill. Depok(ID): Fakultas Matematika dan Ilmu Pengetahuan Alam Program Studi Fisika.

Fatmawati S, Subiantoro, Ridwanto W. 2012. Pemanfaatan kulit telur ayam sebagai pengganti obat luka gores. Banten.

Gorrasi G, Sorrentino A. 2015. Mechanical milling as a technology to produce structural and functional bio-nanocomposites. Green Chemistry. 17(5): 2610-2625. https://doi.org/10.1039/c5gc00029g

Hincke MT, Nys Y, Gautron J, Mann K, Rodriguez-Navarro AB, McKee M. 2012. The eggshell: structure, composition and mineralization. Frontiers in Bioscience. 17(2012): 1266-1280. https://doi.org/10.1109/epqu.2011.612896 6.

Kamba AS, Ismail M, Azmi T, Ibrahim T, Abu Z, Zakaria B. 2013. Synthesis and characterisation of calcium carbonate aragonite nanocrystals from cockle shell powder (Anadara granosa). Journal of Nanomaterials Potential. 1-9. https://doi.org/10.1155/2013/398357.
Khandelwal H, Prakash S. 2016. Synthesis and characterization of hydroxyapatite powder by eggshell. Journal of Minerals and Materials Characterization and Engineering. $\quad 4$ : 119-126. https://doi.org/10.4236/jmmce.2016.42011

Kurniawan A, Nizar M, Rijal M, Bagas R, Setyarsih W. 2014. Studi pengaruh variasi suhu kalsinasi terhadap kekerasan bentuk morfologi, dan analisis porositas nanokompositas $\mathrm{CaO} / \mathrm{SiO}_{2}$ untuk aplikasi bahan biomaterial. Jurnal Penelitian Fisika dan Aplikasinya (JPFA). 4(2): 2226.

Nys Y, Gautron J, Garcia-ruiz JM, Hincke MT. 2004. Avian eggshell mineralization: biochemical and functional characterization of matrix proteins. Comptes Rendus Palevol. 3(6-7): 549-562. https://doi.org/10.1016/j.crpv.2004.08.002.

Rivera EM, Araiza M, Brostow W, Castano VM, Hernandez R, Rodriguez JR. 1999. Synthesis of hydroxyapatite from eggshells. Materials Letters. 41: 128-134.

Shakhashiri. (2000). LIME : CALCIUM OXIDE CaO. pp: 1-2.

Shi Z, Jiang Y, Zhou L, Gao J. 2017. Eggshellderived catalyst for biodiesel production in the presence of acetone as co-solvent. Energy Sources, Part A: Recovery, Utilization, and Environmental Effects. 39(3): 320-325.

Shiferaw N, Habte L, Thenepalli T, Ahn JW. 2019. Effect of eggshell powder on the hydration of cement paste. Materials. 12(15): 1-12. https://doi.org/10.3390/ma12152483

Tangboriboon N, Kunanuruksapong R, Sirivat A. 2012. Preparation and properties of calcium oxide from eggshells via calcination. Materials Science Poland. 30(4): 313-322.

Yew MC, Sulong NHR, Yew MK, Amalina MA, Johan MR. 2014. Fire propagation performance of intumescent fire protective coatings using eggshells as a novel biofiller. Scientific World Journal. 2014: 1-9. https://doi.org/10.1155/2014/805094. 